\section{National Black HIV/AIDS Awareness Day - February 7, 2018}

National Black HIV/AIDS Awareness Day is observed each year on February 7 to emphasize the continuing disproportionate impact of human immunodeficiency virus (HIV) infection and acquired immunodeficiency syndrome (AIDS) on the U.S. black/African American (black) population.

In 2014, non-Hispanic blacks represented $12 \%$ of the U.S. population (1), and the estimated 471,500 blacks living with diagnosed and undiagnosed HIV infection accounted for $43 \%$ of all persons living with diagnosed and undiagnosed HIV (2). In 2016, blacks represented 12\% of the U.S. population (1), and blacks with new HIV diagnoses accounted for $44 \%$ of all new HIV diagnoses (https://www.cdc.gov/ hiv/pdf/library/reports/surveillance/cdc-hiv-surveillance-report2016-vol-28.pdf).

In 2014, among blacks living with diagnosed HIV infection, in 38 jurisdictions with complete reporting of CD4 and viral load data, $69.8 \%$ received HIV medical care, and $51.5 \%$ were virally suppressed (viral load test of $<200$ copies of HIV $\mathrm{RNA} / \mathrm{mL}$ ) (2). A study reported in this issue of $M M W R$ found racial and ethnic disparities in viral suppression and transmission risk (3).

CDC supports a range of efforts to reduce the risk for acquiring or transmitting HIV infection among blacks. Additional information is available at https://www.cdc. gov/features/BlackHIVAIDSAwareness.

\section{References}

1. US Census Bureau. Population and Housing Unit Estimates Datasets 2016. Washington, DC: US Census Bureau; 2016. https://www.census.gov/ programs-surveys/popest/data/data-sets.2016.html

2. CDC. Diagnosis of HIV infection in the United States and dependent areas, 2016. HIV surveillance report, 2016, vol. 28. Atlanta, GA: US Department of Health and Human Services, CDC; 2017. https://www.cdc.gov/hiv/pdf/ library/reports/surveillance/cdc-hiv-surveillance-report-2016-vol-28.pdf

3. Crepaz N, Dong X, Wang X, Hernandez AL, Hall HI. Racial and ethnic disparities in sustained viral suppression and transmission risk potential among persons receiving HIV care-United States, 2014. MMWR Morb Mortal Wkly Rep 2018;67:113-8.

\section{Racial and Ethnic Disparities in Sustained Viral Suppression and Transmission Risk Potential Among Persons Receiving HIV Care - United States, 2014}

\author{
Nicole Crepaz, $\mathrm{PhD}^{1}$; Xueyuan Dong, $\mathrm{PhD}^{1}$; Xiao Wang, $\mathrm{MPH}^{1}$; \\ Angela L. Hernandez, MD ${ }^{1}$; H. Irene Hall, $\mathrm{PhD}^{1}$
}

Non-Hispanic blacks/African Americans (blacks) represent $12 \%$ of the U.S. population.* However, in 2014 an estimated $43 \%(471,500)$ of persons living with diagnosed and undiagnosed human immunodeficiency virus (HIV) infection were blacks (1). In 2016, blacks accounted for 44\% of all new HIV diagnoses (2). Although antiretroviral therapy (ART) prescriptions among persons in HIV care increased overall from $89 \%$ in 2009 to $94 \%$ in 2013, fewer blacks than Hispanics or Latinos

*https://www.census.gov/programs-surveys/popest/data/data-sets.2016.html.

\title{
INSIDE
}

119 Cigarette Brand Preference and Pro-Tobacco Advertising Among Middle and High School Students — United States, 2012-2016

125 Acute IIInesses and Injuries Related to Total Release Foggers - 10 States, 2007-2015

131 Outbreak of Seoul Virus Among Rats and Rat Owners - United States and Canada, 2017

135 Notes from the Field: Public Health Response to a Human Immunodeficiency Virus Outbreak Associated with Unsafe Injection Practices — Roka Commune, Cambodia, 2016

137 Notice to Readers

138 QuickStats

Continuing Education examination available at https://www.cdc.gov/mmwr/cme/conted_info.html\#weekly.

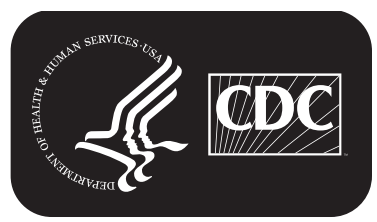

